\title{
ENTRENCHING ABORIGINAL SELF-GOVERNMENT IN CANADA: THE CONSTITUTIONAL APPROACH
}

\author{
By \&DQGDFHO RRHUV
}

\section{Abstract}

Ce texte cherche à savoir si les amendements constitutionnels proposées récemment permettront l'émancipation désirées par les Premières Nations du Canada. En premier, ce texte examine les statuts passés et présents des premières nations dans leurs relations avec le gouvernement fédéral. Il étudie ensuite les effets de la réponse du gouvernement. Il termine avec une analyse de l'avenir des droits indigènes au Canada, concluant que la réforme proposée ne peut pas faire plus de mal que ce qui a été déjà fait.

The idea of self-government for any nation would imply the sovereign status of a state under international law. However, for the First Nations of Canada, more than fifty distinct societies and less than four per cent of the population, the definition of "the inherent right to aboriginal self-government" remains a contentious debate, as its definition varies from one community to the next, and is perceived by the Canadian government as "the Indian problem." Many attempts at recognizing aboriginals' right to self-government within the context of constitutional principles have been an ongoing struggle ever since the British North America Act of 1876. In order to understand the strengths and weaknesses of the proposed constitutional amendments regarding Aboriginal rights, one must first examine the present and past statuses of First Nations in their relations with the federal government. ${ }^{1}$ 
Presently, section 35 of the Canadian Constitution explicitly confirms the recognition of "existing aboriginal and treaty rights of the aboriginal people of Canada." It further defines the terms "aboriginal" to include Indian, Inuit and Métis peoples, and "treaty rights" to refer to land claim agreements. However, debate ensues upon the recognition to include "inherent" as part of the "rights" clause, as in a right that needs not be appointed by any form of government, rather, one that already exits, vested in facts of Aboriginality. It is assumed that this legislation will provide a stepping-stone towards the amelioration of existing First Nations conditions (whose statistics on incarceration, poverty, violence, suicide and infant mortality rates are more appalling than the Canadian norm) through the establishment of governing institutions of aboriginal selfdetermination. Policy reform is indeed imminent, although whether or not such a constitutional amendment will provide emancipation for First Nations is debatable. Self-governance is definitely the key issue, as negotiations between the federal government and Native peoples, on a Nation to Nation basis, certainly cannot possibly do more harm than has already been done.

Historically, the federal government's mandate concerning aboriginal citizens has been one of assimilation. In the British North America Act, 1867, the federal government assumed jurisdiction and authority over "Indians, and Lands reserved for the Indians." Nine years later, 1876, the Indian Act went into effect, furthering the oppression of Native people, with a distinct set of laws that assumed absolute control over Indian people, their lands and their resources in Canada. ${ }^{3}$ Similarly, in 1969, the federal government, led by Prime Minister Pierre Trudeau, introduced a white paper announcing its intention to abolish aboriginal rights in Canada. Since much opposition was met by new resistance group such as the Assembly of First Nations (then known as the National Indian Brotherhood), however, this latter piece of legislation was shelved. Furthermore, the white paper was said to be unconstitutional, "dismissing aboriginal title claims and trivializing treaty rights." What all of these policy measures have in common is the prevailing assumption that aboriginal people were a problem to be dealt with, objects of government policy. The disenfranchisement of several thousand Canadian residents was inherently the country's mandate, however, an opposite shift towards co-operation between the federal government and aboriginals during the past few decades may presently be observed (and wholeheartedly welcomed by Native lobbying groups). 
This new shift in government policy, where the inclination to co-operate with Aboriginal groups on a Nation-to-Nation basis, has occurred since the drafting of the 1982 Constitution Act. This phenomenon may partly be due to Section 35 and its reaffirmation of aboriginal rights, as well as the failed Meech Lake Accord of 1987. There were many reasons that contributed to the failure of Meech Lake, although the inability to deal with aboriginal issues may have been the ultimate reason for its demise. Manitoba's Elijah Harper surely would have reacted otherwise had aboriginal self-government provisions been included in the list of constitutional amendments. Further, having understood the importance of including aboriginal groups in constitutional negotiations, the federal government invited what has been considered "a third level of government" into the round of talks. At the Charlottetown Conference, 1992, not only were the first ministers and premiers of the two territories present, but also leaders of the four national aboriginal organizations participated. Hence, one may observe that Canada's perception of what was formerly the "Indian problem" has necessarily progressed towards a negotiation procedure with a "third level of government." In due time, one can only assume that a Nation to Nation relationship might be applied, via a series of negotiations towards the practical implementation to the existing (inherent) right of aboriginal self-government.

Although the implementation of aboriginal self-government sounds really good in theory, the negotiation procedure will prove to be a long, expensive and complicated process. However, these negotiations are necessary for a variety of reasons. First, definitions need to be drawn on the scope of First Nations selfgovernments that will evolve. Self-government, for Canada's aboriginals, essentially means the incorporation of aboriginal modes of decision-making more consistent with their traditional ways into their own governments while retaining the rights and freedoms they possess as Canadians. ${ }^{5}$ With the precedent set by the Yukon self-governments agreements, ratified in 1993, several substantive provisions emerged to define the status of aboriginal governments in relation to the federal, provincial and territorial administrations. These six key provisions have addressed such issues as a Constitution for First Nations, citizenship codes, the rights of non-aboriginals, the jurisdiction of First Nations, the financing of First Nations governments and the intergovernmental relations that will ensue. ${ }^{6}$ These negotiations towards the implementation of self-government are crucial to render the effectiveness of the aboriginal rights provision in the present Constitution.

Moreover, these negotiations between Aboriginal groups are pro-active 
measures towards the implementation of self-government. They may proceed without the recognition of "inherent" aboriginal rights in the Constitution, as there are many barriers to amending the Constitution as such. For example, one may put forth the assumption that Canada is caught in a constitutional deadlock. The amendment procedures are too rigid, unwelcome to any changes that may resolve some of the country's most vital political challenges. ${ }^{7}$ As well, a number of provinces have refused to recognize aboriginal rights, let alone accepting the amendment constitutionally. The government of Canada, also, is disinterested in reopening debates on constitutional changes. However, despite these barriers to the constitutional recognition of the inherent aboriginal rights, the federal government will act on this assumption as a matter of policy.

Nevertheless, negotiations will not ensure that aboriginals in all areas of the country will enjoy the same political and social reforms. For this reason, some Aboriginal writers are more in favour of the constitutional approach in comparison to the more common reliance on treaties. Dan Russell, a lawyer in Toronto, writes on the difficulty of Aboriginal people on their "standing" in the treaty-making process, as they are not recognized as a sovereign state: "The difficulty for Aboriginal people seeking to utilize the treaty option is that no Aboriginal people in Canada possess this internationally recognized distinction." ${ }^{8}$ Another argument is that treaties are inherently colonial in their nature. Often, a treaty entails a surrender of resources, such as land for rights or vice-versa. Treaties will not gain sympathy from those who insist that Aboriginals have an "inherent" right to both, land and rights, as they have been stripped of these by colonials. Or, otherwise, a pact that does involve a transfer of land is practically unfathomable as Aboriginal people assert that there is currently an insufficient land base to support existing populations as it is. ${ }^{9}$ Therefore, treaties, although they would provide a variety of formats for governance to meet the variety of aboriginal societies, should not be an option. The Jean Chrétien government has also alluded to the fact that when negotiating with Aboriginal groups, they will maintain that they are monolithic, and any political reforms granted would apply to all. ${ }^{10}$

Overall, governmental reforms are indeed imminent to better the social conditions of Aboriginal people, as the empirical evidence suggests are worse than the Canadian norm. As well, these institutional reforms should be applied 
on the basis of Aboriginal self-determination. A recognition of the inherent right to assume these political and social changes should be applied, if not constitutionally, at least in practice, as the government of Canada has indeed done (and is still doing). Further, negotiations should entail a Nation-to-Nation approach, not one of treaties, as these seemingly appear colonial in their nature. Negotiations agreed upon by all levels of government must also prevail in order to define all the substantive provisions that will necessarily evolve from such a dramatic change in government policy. Aboriginal self-government an inherent right? They'd say so. And progress in underway.

\section{ENDNOTES}

1 'First Nations' in this essay include the Labrador Inuit, although the Inuit do not normally label themselves as such. 'First Nations,' in this case, may be interchangeable with the term 'Aboriginals,' simply for ease of expression.

${ }^{2}$ Jackson et al. 599.

${ }^{3}$ Morrisseau 6.

${ }^{4}$ Gibbins 306.

${ }^{5}$ Whittington 109.

${ }^{6}$ Ibid. 116-123.

${ }^{7}$ Jackson et al. 195.

${ }^{8}$ Russell 45. 
${ }^{9}$ Ibid. 46.

${ }^{10}$ Whittington 110.

\section{BIBLIOGRAPHY}

Gibbins, Roger. "Canadian Indians and the Canadian Constitution: A Difficult Passage Toward an Uncertain Destination." Arduous Journey: Canadian Indians and Decolonization. Ed. J. Rick Ponting. Toronto: McClelland and Stewart, 1986. 302-16.

Hylton, John H. "Future Prospects for Aboriginal Self-Government in Canada." Aboriginal Self-Government in Canada. Ed. John H. Hylton. $2^{\text {nd }}$ ed. Saskatoon: Purich, 1999. 432-55.

Jackson, Robert J. and Doreen Jackson. Politics in Canada. $5^{\text {th }}$ ed. Toronto: Prentice Hall, 2001.

McDonnell, R.F. and R.C. Depew. "Aboriginal self-Government and SelfDetermination in Canada: A Critical Commentary." Aboriginal Self-Government in Canada. Ed. John H. Hylton. $2^{\text {nd }}$ ed. Saskatoon: Purich, 1999. 352-76.

Morrisseau, Miles. "Is Self-Government a Mirage?" Compass 10.5 (1992): 6-8.

Morse, Bradford W. "The Inherent Right of Aboriginal Self-Governance." Aboriginal Self-Government in Canada. Ed. John H. Hylton. $2^{\text {nd }}$ ed. Saskatoon: Purich, 1999. 16-44.

Ponting, J. Rick. "Part Four: Indian Self-Government: Editor's Introduction." Arduous Journey: Canadian Indians and Decolonization. Ed. J. Rick Ponting. 
Toronto: McClelland and Stewart, 1986. 318-26.

Special Parliamentary Committee on Indian Self-Government. "Proposals for Indian Self-Government." Arduous Journey: Canadian Indians and

Decolonization. Ed. J. Rick Ponting. Toronto: McClelland and Stewart, 1986. $327-41$.

Russell, Dan. A People's Dream: Aboriginal Self-Government in Canada. Vancouver: UBC, 2000.

Whittington, Michael S. "Aboriginal Self-Government in Canada." Canadian Politics in the 21 rst Century. Eds. Michael S. Whittington and Glen Williams. Scarborough: Nelson, 2000. 105-125. 